This item was submitted to Loughborough's Research Repository by the author.

Items in Figshare are protected by copyright, with all rights reserved, unless otherwise indicated.

\title{
Diaspora as process: (de)constructing boundaries
}

PLEASE CITE THE PUBLISHED VERSION

http://onlinelibrary.wiley.com/doi/10.1111/j.1749-8198.2007.00033.x/abstract

PUBLISHER

(c) Wiley-Blackwell

VERSION

AM (Accepted Manuscript)

LICENCE

CC BY-NC-ND 4.0

REPOSITORY RECORD

Mavroudi, Elizabeth. 2019. "Diaspora as Process: (de)constructing Boundaries". figshare.

https://hdl.handle.net/2134/8832. 
This item was submitted to Loughborough's Institutional Repository (https://dspace.lboro.ac.uk/) by the author and is made available under the following Creative Commons Licence conditions.

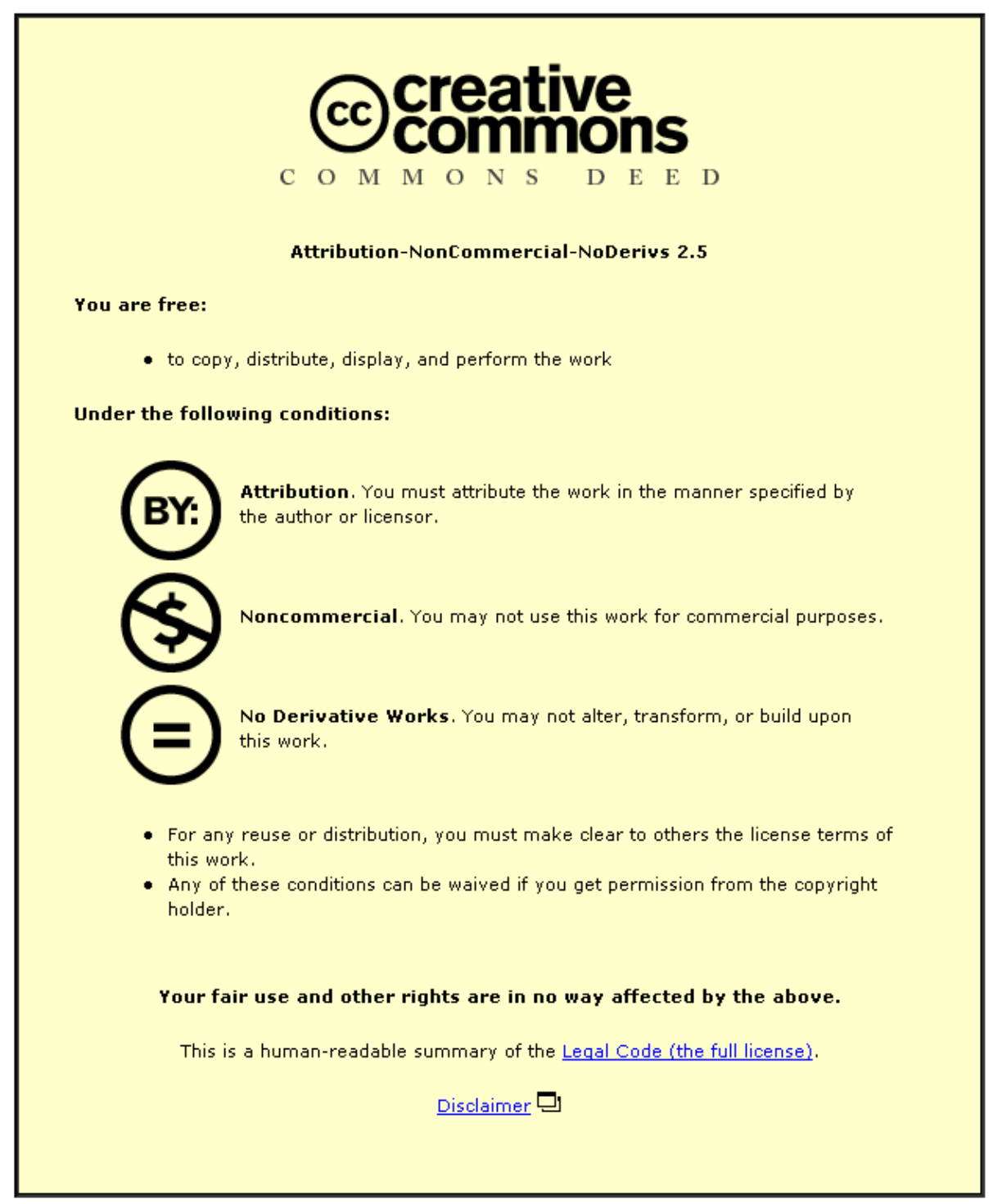

For the full text of this licence, please go to: http://creativecommons.org/licenses/by-nc-nd/2.5/ 


\title{
Diaspora as process: (de)constructing boundaries
}

\begin{abstract}
This article discusses different conceptualisations of diaspora, as bounded, unbounded and as a process, in order to help highlight the useful role diaspora can play in explorations and (de)constructions of nation-state, community and identity boundaries. There are two main ways in which diaspora has been theorised. The first theorises diaspora in relation to defined homeland-orientated ethnic groups and identities and the second theorises diaspora in relation to fluid, non-essentialised, nomadic identities. This article argues that it is necessary to look beyond such conceptualisations of diaspora as nomadic/fluid (unbounded) or homeland-centred/ ethnic-religious (bounded). This article advocates a flexible use of diaspora as process that is able to examine the dynamic negotiations of collective, strategic and politicised identities based around constructions of 'sameness' and the homeland, as well as individual identities that are malleable, hybrid and multiple. It stresses that it is within this notion of diaspora as process that geographers, with their emphasis on place, space and time, have an important role to play.
\end{abstract}

Key words: diaspora, boundaries, identity, community, nation-state, geography

\section{Introduction}

There has been a proliferation of work across the social sciences and humanities that has engaged with the notion of diaspora. Debates about diaspora have become important within geography. Geographers are increasingly contributing to these debates in order to understand changing relationships between space, time and place in relation to notions such as identity, in the midst of current concerns such as globalisation, migration and transnationalism. From a time when diaspora was seen as under-theorised (Safran 1991), popular and academic uses of diaspora have risen dramatically and for Brubaker (2005), this has resulted in what he calls the 'diaspora' diaspora, or a dispersion (and potential fragmentation) of what diaspora actually means.

There have, as a result, been numerous attempts to try and define and explain what diaspora entails. These range from Cohen's (1997) and Sheffer's (1999) typologies and groupings of diaspora, as well as Ember et al's (2004) Encyclopaedia 
of Diasporas to Vertovec's (1997) categories of diaspora as social form, type of consciousness and mode of cultural production, to Butler's identification of points of commonality (2001). They also include work of theorists such as Clifford (1997) and Gilroy (1993) that focuses on fluidity and anti-essentialism. What appears to unite many notions of diaspora is a concern with boundaries or what Brubaker $(2005,6)$ has called 'boundary-maintenance'. However, as he goes on to comment, "there is .... a tension in the literature between boundary-maintenance and boundary erosion. The tension is only occasionally acknowledged".

This is an important issue that conceptualisations of diaspora have to deal with. On the one hand, traditional definitions of diaspora centre around the creation of boundaries (of identity, community and the nation-state) and a focus on roots and the homeland. On the other hand, there are many postmodern conceptualisations of diaspora that are based on ideas of fluidity, movement, routes and the destabilisation of (potentially) homogenising boundaries (of identity, community and the nationstate). As Werbner $(2002,120)$ has noted: "diasporas, it seems, are both ethnicparochial and cosmopolitan. The challenge remains, however, to disclose how the tensions between these two tendencies are played out". Carter $(2005,54)$, for example, is critical of much of the literature on diasporas, which he feels "fails to acknowledge that diasporas can also reproduce the essentialised notions of place and identity that they are supposed to transgress".

A move beyond such potentially problematic and apparently opposing views of diaspora can be seen in the literature. Brubaker $(2005,13)$, for example, feels it is more useful to discuss diasporic "stances, projects, claims, idioms, practices and so on', rather than 'a' or 'the' diaspora. In his critique, Sökefeld $(2006,265)$ focuses on the "formation of diaspora communities as an instance of mobilization processes" using social movement theory. Soysal (2000) and Anthias (1998) have also both been critical of traditional notions of diaspora. Anthias (1998), in particular, argues that more attention needs to be paid to the exploration of what she calls 'intersectionality', or issues of class, gender, and trans-ethnic alliances. A focus on materiality is also stressed by theorists such as Werbner (2000) and by geographers such as Mitchell (1997a) and Blunt (2003, 2005).

The use of a geographical approach to diaspora is discussed by Ní Laoire (2003) in an editorial for a special issue on 'geographies of diaspora'. For Samers, $(2003,353)$ such an approach stresses the need to explore the processes that "produce 
diasporic practices, rather than assume its condition exists a priori”. For Carter (2005, 62 ), it is the 'geopolitics of diaspora' which utilizes "specific histories, maps, interventions and trajectories of diaspora" that needs to be explored. This paper aims to add to such conceptualisations of diaspora in order to help move beyond the problematic tensions between bounded and unbounded notions of diaspora, whilst still bearing in mind that "no single definition of diaspora can be useful" (Shuval 2000, 49). With this in mind, the paper first discusses notions of diaspora as bounded; this is followed by an exploration of cultural understandings of diaspora as unbounded and fluid. It ends with an analysis of diaspora as process, and highlights the potential role that geographers have to play in notions of diaspora.

\section{Diaspora as bounded}

Traditional or classical notions of diaspora have been seen as portraying 'closed' homogenous and stereotypical ethnic and religious entities round the world (Werbner 1998) that may be based on more purist notions of a defined culture, community and identity. As Soysal $(2000,2)$ notes: "the dominant conceptualisations of diaspora presumptively accept the formation of tightly bounded communities and solidarities (on the basis of common cultural and ethnic references) between places of origin and arrival". Safran's (1991, 83-84) definition and categorisation of diaspora provides an example of such an approach. Within such definitions, space, place and identity are often portrayed as stable categories. The nation-state itself (or the ideal of one) may also not be questioned. For example, Cohen (1999) has advocated the importance of a 'primordial identity' in relation to diaspora and he has also described diasporas (1997, 2) as:

positioned somewhere between nation-states and 'travelling cultures' in that they involve dwelling in a nation-state in a physical sense, but travelling in an astral or spiritual sense that falls outside the nationstate’s space/time zone.

Cohen's description here may be useful superficially as it recognises the 'travelling' nature of diaspora but it fails to fully explore such 'travelling' and invariably falls back into the normalised (and easy) category and space of the nation-state. 
Traditional definitions of diaspora invariably revolve around this need to organise and categorise. In doing so, their "conceptual shortcomings...derive in many aspects from unspoken and rather cosy connotations of "community"' (Sökefeld, 2006, 280). Diaspora is thus often used to describe groups of displaced and exiled people who feel they possess a shared ethnicity, culture, (imagined) community and traditions but at the same time, have a relationship, whether real or imagined, to a perceived homeland. As Gupta and Ferguson $(1997,39)$ point out:

Remembered places...often serve as symbolic anchors of community for dispersed people. This has long been true of immigrants who use memory of place to construct their new world imaginatively. "Homeland" in this way remains one of the most powerful unifying symbols for mobile and displaced peoples.

The homeland often becomes a static place, in which they may invest, symbolically, politically, economically and culturally. The salience of concepts such as "collective memories" (Said 2000), shared language and beliefs as well as the homeland become important as they are perceived to encourage dispersed peoples to focus on the arbitrary and potentially homogenous construction of boundaries in relation to the nation-state, identity and community that they are then able to feel 'at home' within. However, they may also serve to achieve political projects, such as homeland-orientated politics and long-distance nationalism (see, for example, Anderson 1998, Fouron and Glick Schiller 2001, Skrbis 1999).

Notions of diaspora as bounded depend on constructions of place, time, identity, community and the nation state as bounded, easily classified and defined. This is why 'diaspora' itself has been criticised for its categorizing tendencies and naturalising and encouraging of nation-state territory-identity associations. As Wimmer and Glick Schiller (2002, 324) stress:

diaspora studies often trace dispersed populations no matter where they have settled, focusing on dynamics of interconnection, nostalgia and memory and identity within a particular population, relating them to a particular homeland. No longer confined to a territorially limited entity, the nation is extending across different terrains and places but 
nevertheless imagined as an organic, integrated whole. In this modus operandi, the nation-state building processes that impinge upon diasporic populations in various locations are usually overlooked.

Traditional notions of diaspora may be seen as compliant with the arbitrary yet normalised associations between identity, community, culture, history and the nationstate that many governments are keen to promote. For example, Brubaker $(2005,10)$ points out that "discussions of diaspora are often informed by a strikingly idealist, teleological understanding of the nation-state, which is seen as the unfolding of an idea of nationalizing and homogenising of the population". In relation to the concept of the nation-state, Shapiro $(2000,80)$ also notes:

the primary understanding of the modern 'nation' segment of the 'nationstate' is that a nation embodies a coherent culture, united on the basis of shared descent or, at least, incorporating a 'people' with a historically stable coherence.

According to Guibernau (2001, 242): "the "nation"” is "a human group that is conscious of forming a community, sharing a common culture, is attached to a clearly demarcated territory, having a common past and a common project for the future and claiming the right to rule itself". Diasporic groups often try to create specific political versions of their identity, 'nation' and community that they feel comfortable with and that can serve as 'fictive unity' (Robins and Aksoy 2001), particularly when they are involved in nation-state building, that can have negative material consequences for those who are not seen to conform.

However, notions of (albeit strategic) essentialism, identity, community and unity are often seen as acceptable ways for those in diaspora involved in political projects to receive recognition as they pursue statehood, equality, justice, an end to discrimination and so forth. For example, Alleyne $(2002,609)$ stresses that: "identities based in ethnic communities have often proved to be politically useful, to provide a sense of solidarity in the face of political and social exclusion". Lavie and Swedenburg $(1996,12)$ have also pointed out that they feel "essentialism is a political necessity, particularly when the group or culture is threatened with radical effacement". 
Tölölyan $(1991,4)$ has noted that "diasporas are the exemplary communities of the transnational moment". Wahlbeck $(1998,14)$ has also described diaspora as "one real and lived transnational experience". Despite the use of cross-border connections those in diaspora may not actively seek to displace the nation-state for it is within bounded notions of the nation-state, identity and community that such groups may perceive power lies. It is easy to discuss those in diaspora as constructing such notions in unproblematic ways without paying attention to the differences, tensions, and power relations that occur in the process and that can create and disrupt notions of homogeneity. The potentially extreme and overly purist nature of such attempts need to be problematised and it is important not to resort to stereotypes and categorisations of those involved in such constructions. Diasporic communities are not necessarily free of "ideologies of purity" (Clifford 1997, 251) or potentially extreme nationalist projects. Communities as group 'solidarities' risk homogenising differences and can be potentially exclusionary for those who fall outside certain idealised ways of being and acting.

Despite the potential for homogenising static and negative constructions of community, the notion of community has also been discussed in a positive manner, and as dynamic and open to interpretation. Kahani-Hopkins and Hopkins (2002, 289) state that "representations of collective identity are anything but neutral for they are bound up with recruiting support for particular political strategies" (ibid.). People within communities can create imagined homogenous spaces, in which there are conflicting identities and tensions, both within and between them (Valentine 2001, 136). Kennedy and Roudometof $(2001,9,17)$ feel, for example, that "communities are units of belonging whose members perceive that they share moral, aesthetic/expressive or cognitive meanings, thereby gaining a sense of personal as well as group identity". Although this can put up boundaries between who is seen as a member and who is not, "communities...are consciously constructed and continuously reinvented" (ibid).

Thus, the notion of community can "become a collectivity which is actively struggled over rather than passively received" (Dwyer 1999, 54). In the process, "communities are imagined contingently and constructed through debate, dialogue and are fluid and changing" (ibid.). Notions of community (as well as identity) are seen as contested, open to varying interpretations (Delanty 2003) and can be ambivalent as well as uncertain (Radcliffe 1999, 37), particularly for those in 
diaspora. At the same time, in-depth research is needed to unravel the intricacies of such constructions. As Wimmer and Glick Schiller (2002, 324) warn, analysing diasporic and transnational migrant "social fields and networks as communities may reify and essentialise these communities".

Despite the widespread academic use of terms such as Anderson's (1983) 'imagined communities' to describe collective feelings of national belonging and cohesion, Robins and Aksoy (2001) dismiss the use of the 'imagined community' to describe the experiences of Turkish Cypriots in London. Instead, they focus on a form of individualism that they borrow from Anthony Cohen, which seeks to "elicit and describe the thoughts and sentiments of individuals which we otherwise gloss over in the generalisations we derive from collective social categories" (Robins and Aksoy 2001, 688, citing Cohen 1994). Such postmodern understandings of identity can be seen in diasporic cultural notions of diaspora as fluid and unbounded.

\section{Diaspora as unbounded}

Conceptualisations of diaspora have tried to counter or move beyond limiting notions of identity that centre solely on the nation-state. Diaspora has become synonymous with celebrations of 'travelling' or nomadic, identities and living 'in-between' spaces and cultures (for example, see Clifford 1997, Gilroy 1993, Brah 1996) and is seen as disrupting the homogeneity of the nation-state.

Cultural interpretations that emphasize and advocate the importance of hybridity and border crossings as ways to understand an increasingly globalised and interconnected world (Clifford 1997) are useful. As a result, identities are seen as hybrid (Bhabha 1994), postcolonial (Young, 2001), malleable, ever-changing representations that may be 'in-between' and always in-the-making (Hall 1990, Minhha 1991, Anzaldúa 1999). Such views on diaspora stress the incomplete, unstable and fluid nature of identities, and cultures generally, insisting on the fallacy of claims of authenticity and hegemonic, artificial, all-encompassing boundaries put around people, nation-states, communities and identities.

Within such conceptualisations of diaspora, feelings of home and belonging are increasingly being seen as affected by the processes of migration and globalisation and can no longer be simplistically theorised and analysed (Al-Ali and Koser 2002). As Rapport and Dawson (1998: 17) stress: "in a world of movement, home becomes an arena where differing interests struggle to define their own spaces within which to 
localise and cultivate their identity". They have argued that home is a concept that is always in motion, moving in and between multiple locations. The idea of home is, therefore, increasingly being seen as flexible, complicated and dynamic.

Within postmodern discussions of diaspora, notion of home have also been seen as contested and relational in order to capture the sense of ambivalence that those in diaspora often feel in relation to home and belonging. The notion of home can raise numerous questions that are often very difficult to answer, clarify and articulate, but which are important aspects of cultural notions of diaspora and a reminder of the arbitrary nature of boundary construction. According to Sarup (1994, 95):

It is usually assumed that a sense of place or belonging gives a person stability. But what makes a place home? Is it wherever your family is, where you have been brought up?...Where is home? Is it where our parents are buried? Is home from where you have been displaced, or where you are now?

Despite their cultural focus, such accounts of diaspora also draw attention to the ways in which negotiation of identity may be a political project that is subversive, resistant and elusive because of the ways in which boundaries (of community, the nation-state and identity) are disrupted, transgressed and potentially ambivalent. They imagine and construct space and place as porous, malleable and unfixed. However useful such poststructural conceptualisations are, they have been criticised for not taking material processes into account (for example, see Mitchell 1997a, Anthias 1998).

The notion of diaspora also needs to take into account the ways in which people are involved in processes of diasporic formation, the fixing and unfixing of boundaries of identity, community and the nation-state, and the ways in which people may be immobile, or caught within and between such borders. Within this, the negotiations of time, space and of place need to be recognised and explored. This can be seen, for example, in Brah's $(1996,180)$ much quoted discussion of diasporic space, which 
marks the intersectionality of contemporary conditions of transmigrancy of people, capital, commodities and culture. It addresses the realm where economic, cultural and political effects of crossing/transgressing different 'borders' are experienced; where contemporary forms of transcultural identities are constituted; and where belonging and otherness is appropriated and contested.

Analysed in such a way diaspora depends on notions of space as malleable, openended and as a process (for example, see Massey 1994, 1999) but that are also material, infused with power relations and can be constructed as bounded and arbitrary for particular reasons. Diaspora as process involves careful scrutiny of the (de)construction of boundaries, in relation to the nation-state, community and identity. It is in the exploration of such processes that geographers have a useful role to play.

\section{Diaspora as process}

The strength of a geographical approach lies in its potential ability to assess and understand diaspora as a process in which space, place and time can be seen as bounded and unbounded within constructions of identity, community and the nationstate. Such a focus is able to take into account the ways individuals and groups negotiate boundaries. As Mitchell (1997b, 110) stresses:

Through geographically informed research and theoretically nuanced understandings of difference and alterity, the difficult questions related to borders and identities will be forced to the surface even if they remain partially unanswered and unanswerable.

According to Ní Laoire (2003, 279), "an explicitly geographical approach to diaspora can result in valuable insights to diaspora studies". She goes on to stress that "understanding diaspora practices and identities requires understanding their location in geographical, historical and material processes" (ibid.).

Geographers are well-placed to theorise and carry out practical research on the construction and negotiation of boundaries in relation to space, and place. As Blunt $(2005,10)$ notes: "while geography is clearly central to understanding diaspora both in theory and practice, ideas about diaspora also raise questions about space and 
place". However, Carter $(2005,55,56)$ points out that "the diaspora literature has failed...to fully explore this transformation of space, beyond re-stating that diaspora consciousness opens up a rift between location and identity" and that as a result, there has been an "inadequate treatment" of territory and of politics. There is, therefore, ample work for geographers to do. Locating and mapping the dynamic complexities of diaspora as process allows us to explore the ways in which people 'on the move' are involved in the negotiation of identities, communities and nation-state building that depend on particular uses (and abuses) of space and place as bounded and unbounded. Such uses may be strategic, politicised, essentialist, anti-essentialist, cultural and so forth.

Houston and Wright (2003, 218, citing Patterson and Kelley 2000) have pointed out that diaspora can be seen as a 'condition' that emphasises "structural features of an exile population" (such as race, gender, class and religion), which can privilege a "static rendition of diaspora and identity". This is why, they argue, notions of diaspora as processes that are 'always in the making' are important. However, the importance of such an approach is not, as Houston and Wright (2003) argue, to 'disrupt' and 're-make' the 'condition' of diaspora but to disrupt the various static constructions of the nation-state and diasporic lives, identities, processes and so forth. 'Structural features' can be unravelled and explored; categorizing them as 'structural' is not necessarily always helpful as they can seem separate to daily materialities, when they are not and it is often a discussion of such 'features' that are missing from traditional accounts of diaspora.

Geographical notions of diaspora as a flexible process do not assume that diaspora is a given, fixed grouping but they acknowledge the need to examine the ways in which displaced people may manipulate and create visions of identity, community and the nation-state that are static, essentialised and fixed for political, socio-economic and cultural reasons. This does not undermine or ignore postmodern constructions of diaspora that celebrate difference, diversity and fluidity. Rather, it adds to them by arguing that an honest and in-depth discussion of such issues requires geographical grounding. In addition, as Samers (2003, 361), in his discussion on Muslim identity in France also notes, it is dangerous to allow diaspora to "cast its powerful shadow over other social relations, such as gender, class, generational conflict, and indeed the state (in countries of both origin and destination". 
At the same time, geographical analyses of diaspora enable the exploration of the process of constructing 'sameness' or collective 'diasporic consciousness', as well as difference, within and across state, community and identity boundaries and the disunities, tensions and in/exclusions that may also occur. As Werbner $(2004,896)$ succinctly notes:

Diasporic communities create arenas for debate and celebration. As mobilised groups, they are cultural, economic, political and social formations in process.... This means that diasporas are culturally and politically reflexive and experimental; they encompass internal arguments of identity about who 'we' are and where we are going. Diasporas are full of division and dissent. At the same time they recognise collective responsibilities, not only to the home country but to co-ethnics in far-flung places.

Diaspora needs to be a broad, open-ended notion that is able to take into account, as Werbner notes, of the cultural, economic, political and social 'formations in process'; such an approach which recognises the complexities and the disjointed potential merging of such factors is useful. Within this, a consideration of processes of power and control within different spaces and scales is important as struggles occur over representation and perceptions of difference.

Notions of diaspora as process problematise the relationships between constructions of (national) identity, community and the nation-state. In turn, this raises questions about the nature of borders and boundaries and of purity and authenticity that notions of diasporas have appeared to be both promoting and disrupting. It is only by recognising and examining dynamic constructions of boundedness and unboundedness that notions of diaspora, as radically transgressive and potentially empowering, can achieve their full potential.

Diaspora has been invested with a great deal of optimism as well as caution and it is a notion that "draws attention to groups of people in a way that is both useful but limiting" (Kalra et al 2006, 27). In their account of diaspora, Kalra et al (2006) end with a pessimistic note that succinctly captures the continuing frustration of diaspora: its inability to effectively challenge the nation-state and the 'norm' of the privileged centre. Although it has been decentred and disrupted, diaspora lacks "the 
means to displace it, and the massive military-legalistic forces that ensure its continuity" (ibid 137). For them, notions of diaspora can only be useful if they actively undermine the nation-state, which many recognise as maintaining power and control over boundaries of the state and identity (see, for example, Ong, 1999).

Yet, the prognosis for diaspora does not have to be negative. It is only through an in-depth understanding of how people in positions of power create boundaries that have the ability to exclude, marginalise and discriminate that such boundaries may begin to be disrupted. The nation-state may still be seen as pervasive, powerful and important (see, for example, Triandafyllidou 1998, Marden 1997), but one could also argue that despite this, it is also being weakened. Although states are continuously involved in the maintenance of boundaries, people continue to find ways to subvert and transgress borders, despite the difficult processes of exclusion, immobility and marginalisation that may also occur.

The inherent need for human mobility and boundary construction will continue and it is the role of academics involved in studies of diaspora, migration and globalisation to help ensure such processes of (im)mobility and boundary construction are as just and ethical as possible. Notions of diaspora need to be to deal with the dominating influences of boundary-maintenance, be it within constructions of community, identity or the nation-state, within and/or across borders. Valentine's $(1999,57)$ assertion that "throughout our everyday lives, we constantly negotiate space, positioning ourselves physically, socially, morally, politically and metaphorically in relation to others" is valid. The material question that remains, however, "in the context of growing global uncertainty, xenophobia and racism" (McEwan 2004), is how to ensure that people (women, men, minorities and so forth) within and across nation-states, self-named (diasporic) groups are not discriminated against as boundaries are (de)constructed and positioned.

\section{Conclusions}

This paper has argued that notions of diaspora have to be flexible enough to move beyond 'bounded' and 'unbounded' paradigms. Although it is important to conceptualise migrants and those in diaspora as being perpetually in movement and travelling, “diaspora journeys are...neither purely emancipatory nor reactionary: instead they are provisional, dependant on the confluence of circumstances and continually elude foreclosure" and are "ridden with disruptions, detours and 
multidestinations" (Yeoh and Huang 2000, 415). This paper advocates a more nuanced, flexible understanding of diaspora that is able to take into account the provisional nature of diaspora as a process, in which notions of time, space and place are not static but are continuously used, imagined and negotiated in the construction of politics of place, or what Nagel (2002) has called the politics of 'sameness' and 'difference'.

In this way, those in diaspora may be seen as dynamic, 'on the move' and multiple but also subject to power relations, tensions, disconnections and the specific, situated processes that enable (or force) the constructions of shared (and often politicised) notions of belonging, identity and community. By studying notions of diaspora in such a way, we may also be better able or equipped to understand the changing relationships between people and places through time and space as they negotiate identities and collectivities across and within boundaries.

Notions of diaspora depend on the exploration of complexity without resorting to easy and arbitrary assumptions about community, identity and the nation-state. It is such assumptions this paper has attempted to deconstruct as a means of illustrating how geography and diaspora may usefully be employed as mutual political projects aimed at disrupting the hegemony and privilege of boundary constructions. By examining particular notions of identity, community and the nation-state, it is possible to explore how differences and similarities are negotiated within cross-cutting spaces, places and times in ways that allow power relations, tensions and in/exclusions to partially appear. The disruptions, messiness and often ambivalence this often provokes can help unsettle notions of purity, authenticity and essentialism.

\section{Short Biography}

Dr Elizabeth Mavroudi is a Teaching/Research Fellow in Geography at the University of Exeter, UK. Before this, she held an ESRC funded Postdoctoral fellowship in the Department of Geography at the University of Durham, UK.

\section{Acknowledgements}

My own research on Palestinians in diaspora, which prompted my interest in the themes this paper was based on, was made possible by Economic and Social Research Council (ESRC) doctoral funding (PTA 030-2002-00600). I would also like to thank Cheryl McEwan for her support and guidance and I am grateful for the comments and advice given by two anonymous referees. 


\section{References}

Al-Ali N and Koser K 2002 New approaches to migration? transnational communities and the transformation of home Routledge, London.

Alleyne B 2002 An idea of community and its discontents: towards a more reflexive sense of belonging in multicultural Britain Ethnic and Racial Studies 254 607-627

Anderson B 1998 The spectre of comparisons: nationalism, Southeast Asia, and the world Verso, London

Anderson B 1983 Imagined communities Verso, London

Anthias F 1998 Evaluating diaspora: beyond ‘ethnicity’? Sociology 323 557-580

Anzaldúa G 1999 Borderlands/La Frontera: The new Mestriza San Francisco, Aunt Lute Books

Bhabha H 1994 The location of culture Routledge, London

Blunt A 2005 Domicile and diaspora: Anglo-Indian women and the spatial politics of home Blackwell, London

Blunt A 2003 Geographies of diaspora and mixed descent: Anglo-Indians in India and Britain International Journal of Population Geography 9 281-294

Brah A 1996 Cartographies of diaspora Routledge, London

Brubaker R 2005 The 'diaspora’ diaspora Ethnic and Racial Studies 28 1 1-19

Butler K D 2001 Defining diaspora, refining a discourse Diaspora 10 189-220

Carter S 2005 The geopolitics of diaspora Area 37 154-63 
Clifford J 1997 Routes: travel and translation in the late twentieth century Harvard University Press, Cambridge

Cohen R 1999 The making of ethnicity: a modest defence of primordialism in $\mathbf{E}$ Mortimer with R Fine (eds.) People, nation and state IB Taurus, London 3-11.

Cohen R 1997 Global Diasporas UCL Press, London

Delanty G 2003 Community Routledge, London

Dwyer C 1999 Contradictions of community: questions of identity for young British Muslim women Environment and Planning A 31 53-68

Ember M, Ember C and Skoggard I 2004 Encyclopaedia of diasporas: immigrant and refugee cultures around the world Springer, New York

Gilroy P 1993 The Black Atlantic: modernity and double consciousness, Routledge, London

Glick Schiller N and Fouron G 2001 Georges woke up laughing: long distance nationalism and the search for home Duke University Press, London and Durham.

Guibernau M 2001 Globalisation and the nation-state in M Guibernau and J Hutchinson (eds.) Understanding nationalism Cambridge, Polity Press, 242-268

Gupta A and Ferguson J eds 1997 Culture, power, place: explorations in critical anthropology Duke University Press, Durham and London

Hall S 1999 Cultural identity and diaspora. In Vertovec, S. and Cohen, R. (eds) Migration, diasporas and transnationalism, Cheltenham: Elgar, 299-314.

Houston S and Wright R 2003 Making and remaking Tibetan diasporic identities Social and Cultural Geography 42 217-232

Kalra V S, Kaur R and Hutnyk J 2006 Diaspora and hybridity Sage, London 
Kahani-Hopkins, V and Hopkins N 2002 'Representing' British Muslims: the strategic dimension to identity construction Ethnic and Racial Studies 252 288-309

Kennedy $\mathbf{P}$ and Roudometof $\mathbf{V} 2001$ Communities across borders under globalising conditions: new immigrants and transnational cultures, ESRC Transnational Communities Research Working Paper WPTC-01-17

Lavie S and Swedenburg T 1996 Introduction: displacement, diaspora and geographies of identity, in S Lavie and T Swedenburg eds Displacement, diaspora and geographies of identity Duke University Press, Durham 1-15

Marden P 1997 Geographies of dissent: globalisation, identity and the nation Political Geography 161 37-64

Massey D 1999 Spaces of politics in D Massey, J Allen and P Sarre eds Human geography today Polity Press, Cambridge 279-294

Massey D 1994 Space, place and gender Polity Press, Cambridge

McEwan C 2004 Travel and transnational spaces in N C Johnson, R Schein and J Duncan Companion to cultural geography Blackwell, Oxford

Minh-ha T 1991 When the moon waxes red: representation, gender and cultural politics Routledge, New York and London

Mitchell K 1997a Different diasporas and the hype of hybridity Environment and Planning D: Society and Space 15 533-553

Mitchell K 1997b Transnational discourse: bringing geography back in Antipode 292 $101-114$

Nagel C 2002 Constructing difference and sameness: the politics of assimilation in London's Arab communities Ethnic and Racial Studies 262 258-287 
Ní Laoire C 2003 Editorial introduction: locating geographies of diaspora International Journal of Population Geography 9 275-280

Ong A 1999 Flexible citizenship: the cultural logics of transnationality Duke University Press, London and Durham

Radcliffe S A 1999 Reimagining the nation: community, difference and national identities among Indigenous and Mestizo provincials in Ecuador Environment and Planning A 31 37-52

Rapport N and Dawson A 1998 The topic and the book in N Rapport and A Dawson eds Migrants of identity: perceptions of home in a world of movement Berg, Oxford and New York 3-17

Robins K and Aksoy A 2001 From spaces of identity to mental spaces: lessons from Turkish-Cypriot cultural experience in Britain Journal of Ethnic and Migration Studies 274 685-711

Said E 2000 Invention, memory and place Critical Inquiry 26 175-192

Safran W 1991 Diasporas in modern societies: myths of homeland and return, Diaspora $183-99$

Samers M 2003 Diaspora unbound: Muslim identity and the erratic regulation of Islam in France International Journal of Population Geography 9 351-364

Sarup M 1994 Home and identity, in G Robertson ed. Travellers' tales: narratives of home and displacement, London: Routledge, 93-104

Shapiro M J 2000 National times and other times: re-thinking citizenship Cultural Studies 141 79-98 
Sheffer G 1999 The emergence of new ethno-national diasporas in S Vertovec and $\mathbf{R}$ Cohen eds Migration, diasporas and transnationalism Elgar, Cheltenham, 396-419.

Shuval J T 2000 Diaspora migration: some definitional ambiguities and a theoretical paradigm International Migration 385 41-57

Skrbis Z 1999 Long-distance nationalism: diasporas, homelands and identities, Ashgate Publishing, Aldershot.

Sökefeld M 2006 Mobilizing in transnational space: a social movement approach to the formation of diaspora Global Networks 63 265-284

Soysal Y 2000 Citizenship and identity: living in diasporas in post-war Europe Ethnic and Racial Studies 23 1 1-15

Tölölyan K 1991 The nation-state and its others: in lieu of a preface Diaspora 1 3-7

Triandafyllidou A 1998 National identity and the 'Other' Ethnic and Racial Studies $214593-612$.

Valentine G 2001 Social geographies: space and society Pearson, Harlow

Valentine G 1999 Imagined geographies: rethinking the 'human' in human geography in Massey D Allen $\mathbf{J}$ and Sarre $\mathbf{P}$ eds Human geography today Polity, Cambridge 47-61

Vertovec S 1997 Three meanings of "diaspora", exemplified among South Asian religions Diaspora 6 277-299

Wahlbeck Ö 1998 Transnationalism and diasporas: the Kurdish example, Paper presented at the International Sociological Association XIV World Congress of Sociology, $26^{\text {th }}$ July $-1^{\text {st }}$ August [online]. Retrieved on $1^{\text {st }}$ February 2007 from: http://www.transcomm.ox.ac.uk/working\%20papers/wahlbeck.pdf 
Werbner P 2004 Theorising complex diasporas: purity and hybridity in the South Asian public sphere in Britain Journal of Ethnic and Migration Studies 305 895-911

Werbner P 2002 The place which is diaspora: citizenship, religion and gender in the making of chaordic transnationalism Journal of Ethnic and Migration Studies 281 $119-133$

Werbner P 2000 Introduction: the materiality of diaspora - between aesthetic and 'real' politics Diaspora 91 5-20

Werbner P 1998 Diasporic political imaginaries: a sphere of freedom or a sphere of illusions? Communal/Plural 61

Wimmer A and Glick Schiller N 2002 Methodological nationalism and beyond: nation-state building, migration and the social sciences Global Networks 24 301-334

Yeoh B and Huang S 2000 Home and away: foreign domestic workers and negotiations of diasporic identity in Singapore Women's Studies International Forum $234413-429$.

Young R 2001 Postcolonialism: an historical introduction Blackwell, Oxford 